\title{
The analysis of COVID-19 impact on the internet and telecommunications service sector through modelling the dependence of shares of Russian companies on the American stock market
}

\author{
A.R. Urazbaeva $\bowtie$, V.A. Voytenkov, R.I. Groznykh \\ Graduate School of Economics and Management, Ural Federal University, Ekaterinburg, Russia; \\ alina.urazbaeva2000@gmail.com
}

\begin{abstract}
Relevance. The coronavirus pandemic has both negative and less obvious positive effects on the world economy. In order to better understand these processes, it is necessary to examine the sectors that have shown growth against the general decline in production. Such sectors include the Internet and telecommunication services. Research objective. The purpose of this study is to model the impact of the pandemic and foreign companies on the value of shares of Russian tech companies. Data and methods. The study involves daily share price data of such American corporations as Google, PayPal, Netflix, Adobe, and the Russian company Yandex. Moreover, we used the dummy variable Covid-19. The econometric analysis was conducted by using vector autoregression (VAR). The direction of cause-and-effect relationships was investigated with the help of the Granger test, and the effect of single shocks, through impulse response functions (IRF). Results. A stable VAR model was built. The IRF graphs were used to describe the impact of the pandemic and the value of US. companies on Russian companies. Conclusions. The study shows that the 2020 pandemic has proven to be a positive shock for companies in the ICT sector, contributing to increased demand for their services and market capitalization. The pandemic has affected both Russian and foreign companies. The study has also found the influence of the American stock market on share prices in Russia. Russian companies reacted to changes in the American stock market with a lag of up to 10 days.
\end{abstract}

\begin{abstract}
KEYWORDS
internet and telecommunication service, COVID-19, share value, American stock market, shares of Russian companies, Yandex, vector autoregression, impulse response function
\end{abstract}

\section{FOR CITATION}

Urazbaeva, A.R., Voytenkov, V.A., \& Groznykh, R.I. (2020)

The analysis of COVID-19 impact on the internet and telecommunications service sector through modelling the dependence of shares of Russian companies on the American stock market. R-economy, 6(3), 162-170. doi: 10.15826/recon.2020.6.3.014

\section{Оценка влияния COVID-19 на отрасль телекоммуникационных услуг посредством моделирования зависимости акций российских компаний от американского фондового рынка}

\author{
А.Р. Уразбаева $\bowtie$, В.А. Войтенков, Р.И. Грозных \\ Институт экономики и управления, Уральский федеральный университет, Екатеринбург, Россия; \\ alina.urazbaeva2000@gmail.com
}

\section{АННОТАЦИЯ}

Актуальность. Пандемия коронавируса имеет как негативные, так и менее очевидные позитивные последствия для мировой экономики. Для понимания происходящих процессов необходимо исследовать сектора, показавшие рост на фоне общего снижения объемов производства. К таким секторам относятся телекоммуникационные услуги. Цель исследования. Целью данного исследования является моделирование зависимости стоимости акций российских компаний телекоммуникационного сектора от влияния COVID-19 и иностранных компаний. Данные и методы. Для исследования использованы ежедневные данные о стоимости акций таких американских корпораций, как Google, PayPal, Netflix, Adobe u российской компании Яндекс. Кроме того, введена дамми-переменная Covid-19. Проведен эконометрический анализ при помощи построения векторной авторегрессии (VAR), исследовано наличие и направление причинно-следственных связей при помощи теста Грэнджера, а также оценено влияние единичных шоков при помощи построения функций импульсного отклика (IRF). Peзультаты. Была построена стабильная VAR-модель и проинтерпретированы ее результаты при помощи графиков функций импульсного отклика. (๑) Urazbaeva, A.R., Voytenkov, V.A., Groznykh, R.I., 2020
\end{abstract}

\section{КЛЮЧЕВЫЕ СЛОВА}

телекоммуникационные услуги, COVID-19, стоимость акций, американский фондовый рынок, акции российских компаний, Яндекс, векторная авторегрессия, функция импульсного отклика 
По результатам анализа было описано влияние пандемии коронавируса, а также акций американских компаний телекоммуникационного сектора на аналогичные российские компании. Выводы. Исследование показывает, что для компаний телекоммуникационного сектора пандемия 2020 года является шоком позитивного характера, способствующим увеличению спроса на услуги компаний и их рыночной капитализации. Установлено, что коронавирус повлиял как на российские, так и на зарубежные компании. Проверена зависимость стоимости акций российских компаний от ситуации на фондовом рынке компаний аналогичного сектора США, при этом выявлен временной лаг реакции российских компаний, составляющий до 10 дней.

\author{
ДЛЯ ЦИТИРОВАНИЯ \\ Urazbaeva, A.R., Voytenkov, V.A., \\ \& Groznykh, R.I. (2020) \\ The analysis of COVID-19 \\ impact on the internet and \\ telecommunications service \\ sector through modelling the \\ dependence of shares of Russian \\ companies on the American stock \\ market. R-economy, 6(3), 162-170. \\ doi: $10.15826 /$ recon.2020.6.3.014
}

\section{Introduction}

As impact of the COVID-19 pandemic on the global economy is becoming more apparent, scholars are trying to estimate the real economic losses in various industries, analyze the consequences of the pandemic for the world economy and predict how long the full recovery will take. There are still heated debates about the effects of the coronavirus on the economy.

According to the International Monetary Fund (2020), the COVID-19 pandemic has had more negative influence on the economic activity in the first half of 2020 than expected, and the estimated recovery is going to be longer than predicted in the World Economic Outlook (WEO) in April. At the moment, global growth is expected at $-4.9 \%$ for 2020 . Figure 1 shows that this is $1.9 \%$ below the WEO forecast (International Monetary Fund, 2020). In addition, the global growth forecast for 2021 is $5.4 \%$.

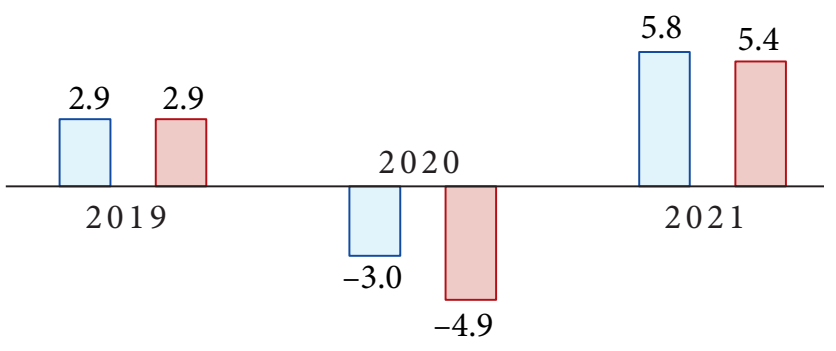

$\square$ WEO April 2020 Update $\square$ WEO June 2020 Update

Figure 1. Projected global growth according to the 2020 World Economic Outlook in April and June, \%

Despite the general decline in production, the pandemic has affected various industries differently. Some industries, such as medicine and the ICT sector, not only recovered rapidly but also showed significant growth (McKinsey, 2020). One of the most revealing indicators for the global economy is the dynamics of share prices in different sectors.
The stock markets have taken the brunt since the prices include negative expectations (Alekseev, 2011). Despite this fact, a paradoxical growth has been demonstrated by the shares of tech companies. This trend seems particularly striking against the general decline. The NASDAQ, which is known for being a predominantly a high-tech exchange, has risen by $10.26 \%$ compared to the pre-COVID level. Hence, the impact of the coronavirus pandemic on companies cannot be considered explicitly negative. The dynamics of shares in the tech sector proves the controversial impact of COVID-19 on the world economy and thus requires more careful examination.

The purpose of this paper is to investigate the impact of the pandemic on the prices of stocks and shares of Russian and foreign companies in the ICT sector. Moreover, we intend to analyze the dynamics of share prices during the coronavirus-induced crisis in order to determine the contribution of foreign companies and the pandemic itself to stock market trends.

\section{Literature review}

So far, there are only a few studies devoted to the pandemic and its impact on companies' performance, which is the research gap we intend to address in this paper.

According to McKinsey's briefing note (July 9, 2020), the sectors most affected by the pandemic such as entertainment, recreation, accommodation, food services, educational services, transportation, warehousing and manufacturing may need more than five years to recover to their pre-COVID-19 level. At the same time, medicine and the Internet and telecommunication services sector tend to be recovering the fastest.

In March, analysts A. Vengranovich and K. Panarin in their interview to Finmarket Information Agency (2020) argued in favor of increasing the attractiveness of various online services for consumers in the long term. Based on 
McKinsey's briefing note (2020), it can be concluded that large IT companies benefit from the changes in the consumption model, for example, the development of online retail.

The same conclusion can be drawn when considering Accenture's "Technology Vision 2020" report of (2020), which was revised to take into account the pandemic and the global crisis. The report suggests that the pandemic has changed the digital experience of consumers and that e-commerce has increased worldwide. For example, in April 2020, Visa reported an 18\% increase in online sales spending in the US and announced that 13 million Latin American Visa cardholders have made their first online transactions in the first quarter of 2020.

Considering the impact of the pandemic as a macroeconomic shock on companies of various sizes we would like to refer to the opinion of M. Zeltser, an expert of informational and analytical portal "BKS Express" (2019). He points out that developing countries tend to be the most sensitive to external factors. Investors have started to avoid buying the stocks of SMEs due to the pandemic, considering them a high risk. The main liquidity flows are directed to large companies. Zeltser remarks that such trends are also described in the studies of TradingAnalysis.com, Strategic Wealth Partners and others. Therefore, due to the fact that large issuers continue to be in high demand, shares of market leaders should be selected as a subject of research since the value of their stocks and shares will be the most indicative during the crisis. Based on the similarity of business processes, we can assume a similar reaction of companies' shares to external and internal shocks. The market mechanism dictates that top executives' performance should increase the value of shares and vice versa (Minasov, 2001).

E.A. Fedorova (2013) uses correlation analysis, causal analysis, VAR modeling and cointegration analysis, and concludes that during the crisis the Russian stock market is influenced by the situation in developed countries, including the USA. US macroeconomic indicators have been found to be crucial for assessing the dynamics of other countries' stock markets (Nikkinen J. et al., 2006). This can be explained by the leading position of the United States in the global economy: since 2000, the share of the United States in world capitalization has been at least 35\% (Asaturov, et al., 2012)

There is a vast research literature on the influence of the US market on other stock markets.
Such studies include G. Dhesi, L. Xiao (2010), Harju, Hussain (2006), Dubreuille, Mai (2009), Caporale, Spagnolo (2011). One of the most revealing articles on this topic is the research by Dhesi G. and Xiao L. (2010), who have tested the hypothesis that the US stock market influences stock market indices of various countries, including the DAX, CAC, FTSE 100, S\&P 500. The authors concluded that the changes in the US stock market affect the volatility of Asian and European markets.

In the study on the risk of developed and emerging markets, M. Zeltser (2019) points out that over a long period, global market trends have been more evident in developed than in emerging markets. In other words, there is a lag between the exposure of developed and emerging markets to macroeconomic shocks.

Drawing on the previous findings we can formulate the following hypotheses:

1. The coronavirus pandemic has been a positive shock to companies in the ICT sector;

2. The impact of shocks is avalanche-like, primarily affecting developed stock markets, which set the direction for emerging markets.

\section{Methods and Data}

To assess the impact of the coronavirus pandemic on Russian companies in the ICT sector, we chose an econometric approach. We use the vector autoregression (VAR) model, which is optimal for obtaining time-series forecasts in the financial and economic sphere. The VAR model can be used for providing short-term forecasts and consider the influence of lag values and factors on the dynamics of endogenous variables (Kamenskiy, 2019).

The research is based on the daily share price data from such companies as Google, PayPal, Netflix, Adobe, and Yandex. There is also a dummy variable called Covid-19. The eventday for this variable is 21.02 .2020 , which was the first significant (on average 5\%) drop in the NASDAQ composite index caused by the disease outbreak.

The sample includes 387 observations from 02.01.2019 to 15.07.2020. The choice of the period is based on the fact that US stock indices had shown constant growth since the beginning of 2019. In 2019 the increase in the NASDAQ composite index was about $30 \%$, which makes the influence of Covid-19 since 21.02.2020 even more noticeable. 
Descriptive statistics

\begin{tabular}{|c|c|c|c|c|c|}
\hline & Yandex & PayPal & Netflix & Google & Adobe \\
\hline Mean & 38.13 & 113.17 & 353.25 & 1249.63 & 308.57 \\
\hline Median & 37.41 & 108.17 & 353.37 & 1218.76 & 293.71 \\
\hline Maximum & 54.82 & 183.23 & 548.73 & 1541.74 & 466.20 \\
\hline Minimum & 26.80 & 82.09 & 254.59 & 1016.06 & 215.70 \\
\hline Std.Dev. & 4.95 & 19.98 & 53.10 & 129.42 & 50.05 \\
\hline Skewness & 0.65 & 1.73 & 0.73 & 0.44 & 1.00 \\
\hline Kurtosis & 3.44 & 5.66 & 3.68 & 2.12 & 3.51 \\
\hline Jarque-Bera & 30.61 & 307.92 & 42.23 & 24.98 & 68.14 \\
\hline Probability & 0.00 & 0.00 & 0.00 & 0.00 & 0.00 \\
\hline Sum & 14756.42 & 43795.49 & 136706.40 & 483607.70 & 119418.40 \\
\hline SumSq.Dev. & 9440.98 & 154068.10 & 1088262.00 & 6465030.00 & 966822.40 \\
\hline Observations & 387.00 & 387.00 & 387.00 & 387.00 & 387.00 \\
\hline
\end{tabular}

Source: authors' calculations based on the statistical data.

Table 1 contains descriptive statistics for the selected variables. The form of market shares value distribution is analyzed. According to the Jarque-Bera criterion, residuals are not normally distributed.

To build a correct autoregressive model, we conducted a preliminary data analysis.

First, we selected exogenous variables. The basic criterion for selecting explanatory variables is the similarity between financial indicators and the coefficients. This methodology has proven to be a complex selection tool that considers various aspects of financial and economic activities of companies. (Zaltsman, 2012; Demeshev and Tikhonova, 2014; Kosmykova, 2016)

The primary selection criterion is the asset turnover ratio (Table 2). It shows the intensity of use of all available assets by the company, that is, how effectively the company manages them. We should note that other companies in the Internet and telecommunication services have distinct ratios: AMD (1.34), Apple (0.81), Cisco (0.74).

Table 2

Asset Turnover Ratio Comparison

\begin{tabular}{|l|c|c|c|c|c|}
\hline \multirow{2}{*}{ Ratio } & \multicolumn{5}{|c|}{ Companies } \\
\cline { 2 - 6 } & Yandex & Netflix & Adobe & PayPal & Google \\
\hline $\begin{array}{l}\text { Asset Turnover } \\
(T T M)\end{array}$ & 0.56 & 0.67 & 0.58 & 0,36 & 0,64 \\
\hline
\end{tabular}

Source: Investing.com

We also divide the indicators into several groups for further comparison. The division includes market valuation, income statement valuation, and one share valuation.
The asset turnover indicates the efficiency of asset utilization, but it does not reflect the market value of the company. The market identically evaluates the following pair by price/earnings indicator (Table 3).

Table 3

Price/Earnings Ratio Comparison

\begin{tabular}{|c|c|c|}
\hline \multirow{2}{*}{ Ratio } & \multicolumn{2}{|c|}{ Companies } \\
\cline { 2 - 3 } & Yandex & Netflix \\
\hline P/E Ratio TTM & 87.08 & 87.36 \\
\hline Source: Investing.com
\end{tabular}

Yandex and Google search engines are considered together due to the fact that each company's fundamental indicators (price/sales volume, price/balance sheet value) take similar values (Table 4).

Table 4

Price to Sales, Price to Book Ratios Comparison

\begin{tabular}{|l|c|c|}
\hline \multirow{2}{*}{\multicolumn{1}{|c|}{ Ratio }} & \multicolumn{2}{c|}{ Companies } \\
\cline { 2 - 3 } & Yandex & Google \\
\hline Price to Sales TTM & 7.41 & 6.21 \\
\hline Price to Book MRQ & 6.18 & 5.09 \\
\hline
\end{tabular}

Source: Investing.com

It is necessary to refer to the indicators calculated by using the profit and loss statement, such as the operating profit margin, pre-tax profit margin, profitability ratio. The values of these coefficients for Yandex are comparable with those of PayPal due to the presence of money transfer services, and with those of Netflix due to the presence of video hosting services (Table 5). 
Table 5

Operating margin, Pretax margin, Net Profit margin Ratios Comparison

\begin{tabular}{|l|c|c|c|}
\hline \multirow{2}{*}{ Ratio } & \multicolumn{3}{|c|}{ Companies } \\
\cline { 2 - 4 } & Yandex & Netflix & PayPal \\
\hline Operating margin TTM, \% & 13.29 & 16.59 & 14.23 \\
\hline Pretax margin TTM, \% & 14.44 & 13.23 & 13.93 \\
\hline Net Profit margin TTM, \% & 7.33 & 11.29 & 10.27 \\
\hline \multicolumn{3}{|c|}{ Source: Investing.com }
\end{tabular}

The last indicator of separation is performance per share. In terms of cash per share, Yandex is the closest to Adobe and PayPal (Table 6).

Table 6

Cash/Share Ratio Comparison

\begin{tabular}{|c|c|c|c|}
\hline \multirow{2}{*}{ Ratio } & \multicolumn{3}{|c|}{ Companies } \\
\cline { 2 - 4 } & Yandex & Adobe & PayPal \\
\hline Cash/Share MRQ & 8.33 & 9.06 & 8.68 \\
\hline Source: Investing.com
\end{tabular}

Such factor as the tangible book value per share is not often used in the analysis, as it may take negative values. However, it is necessary for research completeness. The coefficients take similar values for Yandex and PayPal (Table 7).

Table 7

Tangible Book Value/Share Ratio Comparison

\begin{tabular}{|c|c|c|}
\hline \multirow{2}{*}{ Ratio } & \multicolumn{2}{|c|}{ Compaies } \\
\cline { 2 - 3 } & Yandex & PayPal \\
\hline Tangible Book Value/Share MRQ & 6.22 & 4.67 \\
\hline Source: Investing.com
\end{tabular}

The similarity of business processes in the given companies, their belonging to the ICT sector and similar values of financial indicators enable us to identify the prices of Google, PayPal, Netflix, and Adobe shares as exogenous for Yandex shares.

In general, fluctuations in the value of shares on the stock market are random walk, similar to the process of first-order autoregression. However, it differs from the stationary process by its properties. The influence of a random error does not fade as time passes. Besides, the variance of this process is not a constant value.

It is necessary to bring the process of the random walk to white noise to study time series. White noise is a stationary process with constant mathematical expectation, constant variance, and zero autocovariance function, for all but zero lag. This is achieved by taking the logarithm of the growth rate, where $r$ is returns, which is yield to the previous period (Equation 1):

$$
r=\ln \left(\frac{P_{t}}{P_{t-1}} \cdot 100 \%-100 \%\right) .
$$

The results of the Dickey-Fuller stationarity test for the initial data of Yandex share price and for the logarithms of the growth rate of Yandex share price are provided in Table 8.

Table 8

Dickey-Fuller stationarity test results

\begin{tabular}{|l|c|c|c|c|}
\hline $\begin{array}{c}\text { Com- } \\
\text { pany }\end{array}$ & $\begin{array}{c}\text { Probabil- } \\
\text { ity value } \\
\text { of initial } \\
\text { data }\end{array}$ & Conclusion & $\begin{array}{c}\text { Probability } \\
\text { value of loga- } \\
\text { rithms of the } \\
\text { growth rate }\end{array}$ & Conclusion \\
\hline Yandex & 0.71 & $\begin{array}{c}\text { Not a } \\
\text { stationary } \\
\text { process }\end{array}$ & 0.00 & $\begin{array}{c}\text { Stationary } \\
\text { process }\end{array}$ \\
\hline PayPall & 0.98 & $\begin{array}{c}\text { Not a } \\
\text { stationary } \\
\text { process }\end{array}$ & 0.00 & $\begin{array}{c}\text { Stationary } \\
\text { process }\end{array}$ \\
\hline Netflix & 0.95 & $\begin{array}{c}\text { Not a } \\
\text { stationary } \\
\text { process } \\
\text { Not a } \\
\text { stationary } \\
\text { process }\end{array}$ & 0.00 & $\begin{array}{c}\text { Stationary } \\
\text { process }\end{array}$ \\
\hline Google & 0.62 & $\begin{array}{c}\text { Not a } \\
\text { stationary } \\
\text { process }\end{array}$ & 0.00 & $\begin{array}{c}\text { Stationary } \\
\text { process } \\
\text { process }\end{array}$ \\
\hline
\end{tabular}

Source: authors' calculations based on the statistical data

Our comparison has shown that this method enables us to smooth out time series and bring them to stationarity. We also performed Granger's test, which proved to be a reliable method for detecting causal relationships between stock prices (Dubrovin, 2009). The null hypothesis of the test is that one variable does not affect another variable. Granger's test interpretations of the direction of cause-effect relationships are presented in Table 9.

Granger's test interpretations

\begin{tabular}{|l|c|c|l|}
\hline Variable & \multicolumn{2}{|c|}{$\begin{array}{c}\text { Probability value for the } \\
\text { hypothesis }\end{array}$} & \multicolumn{1}{|c|}{ Interpretation } \\
\cline { 2 - 3 } & $\begin{array}{c}\text { Yandex does } \\
\text { not Granger } \\
\text { Cause } \\
\text { Variable }\end{array}$ & $\begin{array}{c}\text { Variable does } \\
\text { not Granger } \\
\text { Cause } \\
\text { Yandex }\end{array}$ & \\
\hline Covid-19 & 0.88 & 0.00 & Yandex $\leftarrow$ Covid-19 \\
\hline Netflix & 0.18 & 0.04 & Yandex $\leftarrow$ Netflix \\
\hline Adobe & 0.18 & 0.01 & Yandex $\leftarrow$ Adobe \\
\hline PayPal & 0.11 & 0.01 & Yandex $\leftarrow$ PayPal \\
\hline Google & 0.01 & 0.01 & Yandex $\leftrightarrow$ Google \\
\hline
\end{tabular}

Source: authors' calculations based on the statistical data

Before examining the main endogenous variable, let us make sure that the pandemic really affects both Russian and foreign companies. Regarding the impact of the coronavirus on US stocks, the picture is the same in all the cases: 
there is a clear indication that all of them are affected by the COVID-19 pandemic.

According to the results of the test, the impact of shares of foreign companies on the shares of Yandex at a significance level of $5 \%$ is noticeable. The opposite effect is observed only for Google. Hence, Granger's test helped us establish the direction of the cause-effect relationship between the variables.

It is important to remember that VAR coefficients cannot be interpreted directly. The influence of one variable on another is not limited by the coefficient standing before it. There is also an indirect influence through other variables (Vakulenko, 2012). In this regard, for the interpretation of the VAR, we chose the analysis of the impulse response functions (IRF). They characterize the time of the return of the endogenous variable to the equilibrium trajectory with a single shock of the exogenous variable (Bannikov, 2006).

\section{Results}

The VAR model of the dependence of Yandex shares on Google, PayPal, Netflix, Adobe and Covid-19 variables is presented as follows (Equation 2). For the model estimation, the logarithms of the following companies' growth rates are taken. Only significant coefficients are presented in the equation. The Student's t-statistics are given in square parentheses, $\varepsilon$ represents residual values.

$$
\begin{aligned}
& \text { Yandex }_{t}=0.1102 \cdot \mathrm{PayPal}_{t-1}- \\
& -\underset{[-2.0211]}{0.1185} \text { PayPal }_{t-3}+0.1018 \cdot \text { Google }_{t-1}+ \\
& +0_{[2.2191]}^{0.1178} \cdot \text { Netflix }_{t-2}+1_{[2.1628]}^{.7049 \cdot} \text { Covid19 }{ }_{t-1}+\varepsilon_{t} \text {. }
\end{aligned}
$$

Despite the insignificance of the coefficient of the variable "Adobe", it was decided not to exclude it from the model, as it can lead to errors in the model specification (Kostyunin, 2019). The insignificance of the coefficient is explained by the specifics of the companies' activity. Although both Yandex and Adobe belong to the Internet and telecommunication sector, the services they provide differ significantly.

It is necessary to conduct certain procedures to choose an adequate lag order. If the selected lag order is too high, the accuracy of the VAR model forecast is reduced. One of them is the lag length criteria (Table 10). For selection, we used such criteria as Hannan-Quinn Criterion (HQ), Akaike's Information Criterion (AIC), Schwarz Criterion (SC).For our analysis, we chose Akaike's Information Criterion (AIC) because of its prevalence.
Table 10

VAR Lag Order Selection Criteria

\begin{tabular}{|c|c|c|}
\hline Lag & AIC & SC \\
\hline 0 & 16.12 & 16.18 \\
\hline 1 & 12.83 & $13.28^{\star}$ \\
\hline 2 & $12.83^{\star}$ & 13.66 \\
\hline 3 & 12.91 & 14.13 \\
\hline 4 & 12.95 & 14.56 \\
\hline 5 & 13.01 & 15.00 \\
\hline 6 & 13.07 & 15.45 \\
\hline 7 & 13.19 & 15.95 \\
\hline 8 & 13.29 & 16.44 \\
\hline
\end{tabular}

* Indicates lag order selected by the criterion

Source: authors' calculations based on the statistical data

The presence of autocorrelation of the first and higher orders is the most frequently encountered problem in time series. The LM test enables us to determine the higher order autocorrelation (Table 11). There is no first or higher order autocorrelation in this model on $95 \%$ confidence interval.

Table 11

VAR Residual Serial Correlation LM Tests

\begin{tabular}{|c|c|c|}
\hline Lags & LM-Stat & Prob \\
\hline 1 & 50.60 & 0.05 \\
\hline 2 & 43.06 & 0.19 \\
\hline 3 & 48.02 & 0.09 \\
\hline 4 & 43.83 & 0.17 \\
\hline 5 & 43.32 & 0.19 \\
\hline 6 & 38.94 & 0.34 \\
\hline 7 & 18.01 & 0.99 \\
\hline 8 & 28.79 & 0.80 \\
\hline 9 & 51.69 & 0.04 \\
\hline 10 & 30.07 & 0.75 \\
\hline 11 & 25.41 & 0.91 \\
\hline 12 & 23.03 & 0.95 \\
\hline
\end{tabular}

Source: authors' calculations based on the statistical data

The presence of heteroscedasticity is a problem that occurs not only in panel data but also in time series. The White's test enables us to identify its presence at the stage of modeling (Table 12). The value of Probability is higher than 0.1 , accordingly, there is no heteroscedasticity in the investigated time series.

Table 12

VAR Residual Heteroskedasticity Tests

\begin{tabular}{|c|c|c|}
\hline \multicolumn{3}{|c|}{ Joint test: } \\
\hline Chi-sq & df & Prob. \\
\hline 633.33 & 693 & 0.95 \\
\hline
\end{tabular}

Source: authors' calculations based on the statistical data 


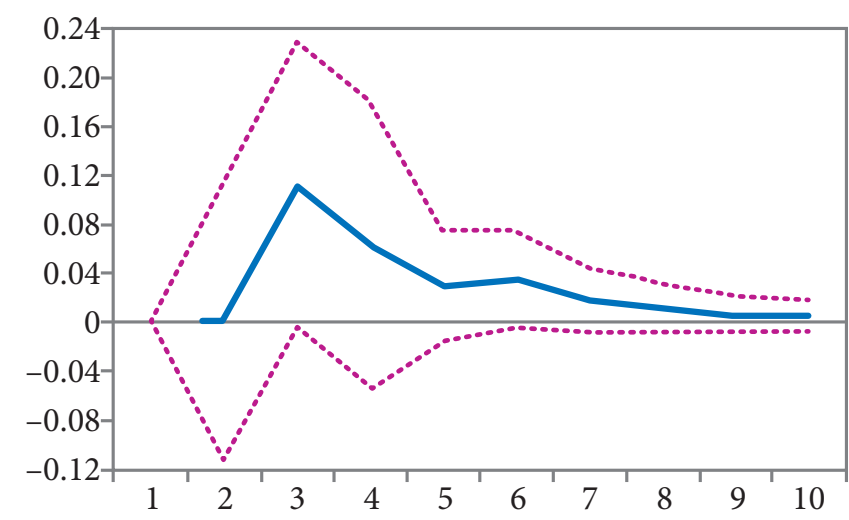

Figure 2. Response of Price of Yandex shares, \$ to Cholesky One S.D Price of Netflix shares, \$

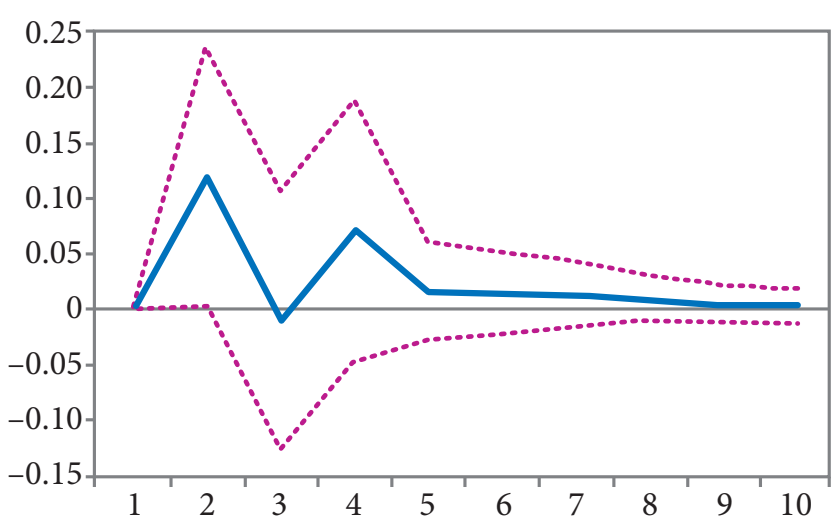

Figure 4. Response of Price of Yandex shares, \$ to Cholesky One S.D Price of Google shares, \$

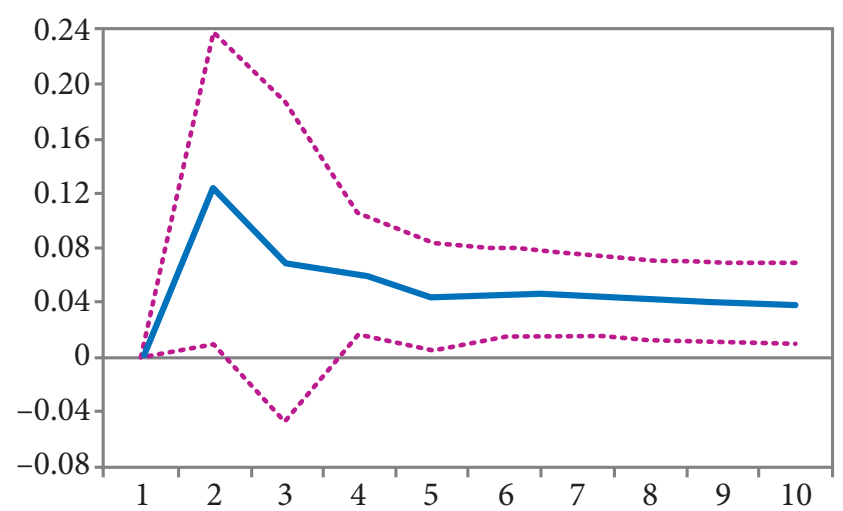

Figure 6. Response of Price of Yandex shares, $\$$ to Cholesky One S.D. Covid-19

The absence of heteroscedasticity and autocorrelation on a $95 \%$ confidence interval lead us to the conclusion that the resulting model is stable. The lag length criteria have enabled us to choose the optimal lag order.

Let us now consider the impulse response functions. According to the charts, single price shocks of shares of foreign companies, in general, cause a positive response to the price of Yandex shares (Figures 2-5).

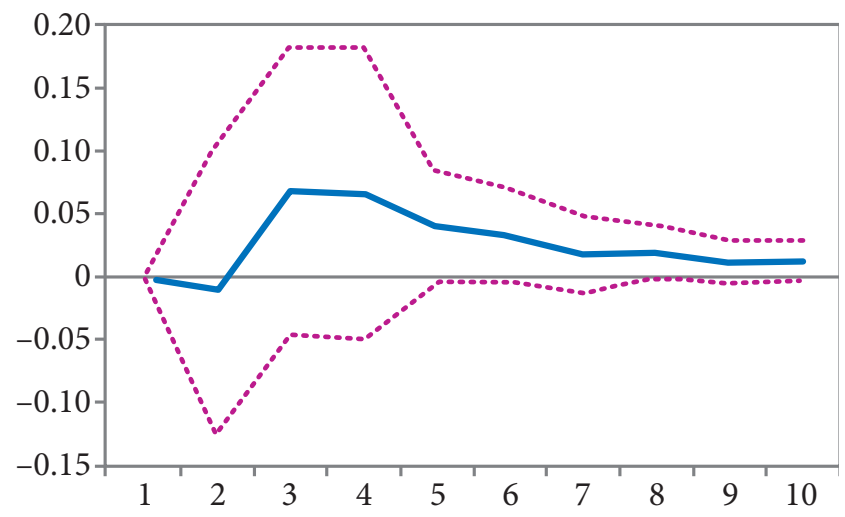

Figure 3. Response of Price of Yandex shares, \$ to Cholesky One S.D Price of Adobe shares, \$

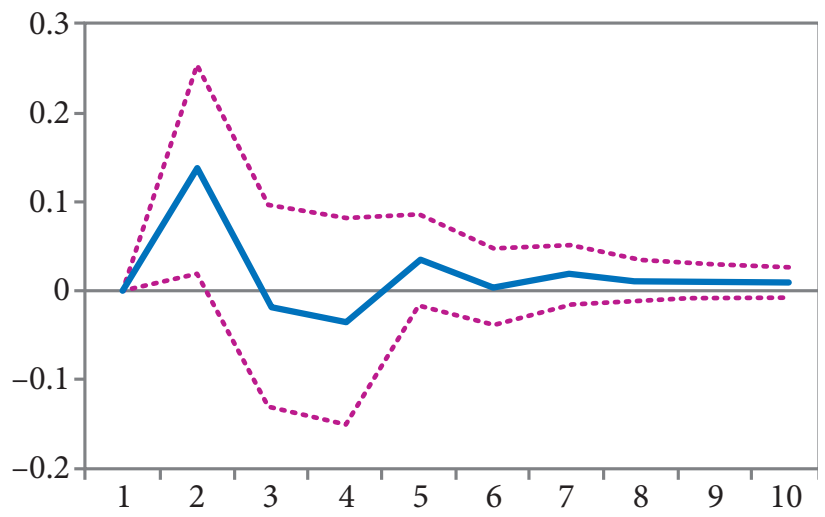

Figure 5. Response of Price of Yandex shares, $\$$ to Cholesky One S.D Price of PayPal shares, \$

The influence of all the given companies decreases significantly during a ten-day period. The coronavirus, on the contrary, does not decline for 10 days and remains constant for 50-70 days (Figure 6).

The influence of companies in terms of strength is comparable to the impact of the pandemic, but the effect of the pandemic persists for a longer period.

\section{Conclusions}

As the quarantine measures in many developed countries are being gradually relaxed and international borders between the countries are being opened, it becomes evident that the economic impact of the pandemic will persist for a while. McKinsey (2020) estimates that the recovery of some industries can extend to 2025. Thus, it is necessary to continue monitoring the situation in the following periods.

The results of the study confirm the findings of Dhesi G., Xiao L. (2010), Harju, Hussain (2006), Dubreuille, Mai (2009), Caporale, Spagnolo (2011) and Nikkinen J. et al (2006), who 
showed the influence of the American stock market on share prices in other countries, including Russia. According to Mikhail Zeltser (2019), this influence is observed with a time lag of about 10 days.

The impulse response function graphs prove that the coronavirus pandemic has been a positive shock for Russian tech companies, which confirms our first hypothesis.

It should be noted that the results of the VAR model show the influence not only of the first lag of foreign companies but also of the second and the third lag, which indicates a delayed impact. Consequently, the second hypothesis about the avalanche-like shock exposure is confirmed.

According to the results of the empirical research, the Russian company operating in the
Internet and telecommunications sector can create an environment that promotes an increase in market capitalization. Other Russian companies, such as MTS, Sberbank, and Mail.ru, can adopt the approach described in this paper.

The dynamic model of diagnostics and forecasting of the value of Yandex shares provides a qualitative assessment of the current situation on the stock market, reveals competitive advantages and problems of IT companies and can also be used to forecast future trends. Our findings can thus be useful for private investors and company managers.

This topic is by far not exhausted and in the future, we are going to use correlation and cointegration analysis to conduct a more detailed study of the impact of external shocks.

\section{References}

A new look at our 2020 Technology Vision trends (2020). Retrieved from Accenture consulting company website: https://www.accenture.com/us-en/insights/technology/tech-vision-coronavirus-trends

Alekseev, D.A. (2011) Mechanisms of the companies capitalization. Irkutsk: BGUEP Publishing House, 150.

Asaturov, K.G., Teplova, T.V., \& Sukhorukova, K.I. (2012) Volatility flow effect on the stock markets (part 2). Financial risk management, 4(32), 254-266.

Bannikov, V.A. (2006) Vector models of the autoregressive and regression residues correction (EViews). Applied econometrics, (3), 96-129.

Caporale, M.G., \& Spagnolo, N. (2011). Stock market integration between three CEECs, Russia and the UK. Review of International Economics, 19(1), 158-169.

COVID-19 and the great reset: Briefing note \#13 (2020, July 9). Retrieved from McKinsey \& Company website: https://www.mckinsey.com/business-functions/risk/our-insights/covid-19-implications-for-business\#

Demeshev B., \& Tikhonova A. (2014). Default prediction for Russian companies: intersectoral comparison. Series WP2 "Quantitative Analysis of Russian Economy". Retrieved from: https:// wp.hse.ru/data/2014/09/20/1315892231/WP2 2014 04.pdf

Dhesi, G., \& Xiao, L. (2010). Dynamic Linkages Between the European and US Stock Markets. 3rd International Conference on Business Intelligence and Financial Engineering, VSIM, Bulgaria, art. no. 5621816, 403-407.

Dubreuille, S., \& Mai, H.M. (2009), Impact of European and American Business Cycle News on Euronext Trading. International Journal of Business 14, 124-135.

Dubrovin, S.S. (2009). Investigation of Causal Relationships in Stock Market Operations. Proceedings of Tula State University. Natural sciences, (2), 167-173. Retrieved from: https://cyberleninka. $\mathrm{ru} /$ article/n/issledovanie-prichinno-sledstvennyh-svyazey-pri-operatsiyah-na-fondovom-rynke

Fedorova, E.A. (2013). Evaluation of influence of the US, Chinese and German stock markets on the Russian stock market. Economic analysis: theory and practice, 47(350), 29-37. Retrieved from: https://cyberleninka.ru/article/n/otsenka-vliyaniya-fondovyh-rynkov-ssha-kitaya-i-germanii-na-fondovyy-rynok-rossii

Harju, K., \& Hussain, S.M. (2011) Intraday Seasonalities and Macroeconomic News Announcements. European Financial Management, 367-390.

Kamenskiy, D.A. (2019). Application of vectorial autoregressive models in forecasting in finance and economics. Fundamental research, (5), 45-49. Retrieved from: https://www.fundamental-research.ru/ru/article/view?id=42459

Kosmykova, T. (2016). Binary enterprise bankruptcy risk assessment models. Science and Innovation, 2(156), 47-50. 
Kostyunin, V.I. (2019) Model Specification, ECONOMETRICA. Textbook and Workshop for Applied Bachelor-M. (pp. 17-36). Moscow: Yureit Publishing House.

Minasov, O.Yu. (2001). Management of market value of shares. Digest Finance, 10(82), 26-34. Retrieved from: https://cyberleninka.ru/article/n/upravlenie-rynochnoy-stoimostyu-aktsiy

Nikkinen, J., Omran, M., Sahlström, P., \& Äijö, J. (2006) Global stock market reactions to scheduled U.S. macroeconomic news announcements. Global Finance Journal, 17(1), 92-104

Technology vision 2020. We, the post-digital people (2020). Retrieved from Accenture consulting company website: https://www.accenture.com/ru-ru/insights/technology/ acnmedia/ Thought-Leadership-Assets/PDF-2/Accenture-Technology-Vision-2020-Full-Report.pdf

The shift in online consumption caused by the coronavirus is positive for TV companies and the IT sector of Russia - Renaissance Capital (2020, March 19). Retrieved from Finmarket Information Agency website: http://www.finmarket.ru/shares/analytics/5195426

Vakulenko, E.S. (2012). Analysis of multidimensional time series. Retrieved from: https://pokrovka11.files.wordpress.com/2012/12/time-series-analysis-part2.pdf

World Economic Outlook Update (2020, June). Retrieved from International Monetary Fund website: https://www.imf.org/en/Publications/WEO/Issues/2020/06/24/WEOUpdateJune2020

World Economic Outlook Update (2020, April). Retrieved from International Monetary Fund website: https://www.imf.org/en/Publications/WEO/Issues/2020/04/14/weo-april-2020

Zaltsman, A. A. (2012) Determinants of dividend policy of Russian public companies. Audit and financial analysis, 1, 233-241. Retrieved from: https://fmlab.hse.ru/data/2012/05/02/1250626792/20 $12 \% \mathrm{D} 0 \% 90 \% \mathrm{D} 0 \% \mathrm{~B} 8 \% \mathrm{D} 0 \% \mathrm{~A} 4 \% \mathrm{D} 0 \% 90 \% \mathrm{D} 0 \% 97 \% \mathrm{D} 0 \% \mathrm{~B} 0 \% \mathrm{D} 0 \% \mathrm{BB} \% \mathrm{D} 1 \% 8 \mathrm{C} \% \mathrm{D} 1 \% 86 \% \mathrm{D} 0 \% \mathrm{~B}-$ C\%D0\%BOD0\%BD_(09)_(233-241).pdf

Zeltser, M. (2019, September 17) Blue chips VS second echelon. What to choose. Retrieved from informational and analytical portal "BKS Express": https://bcs-express.ru/novosti-i-analitika/golubye-fishki-vs-vtoroi-eshelon-chto-vybrat

Zeltser, M. (2019, September 6) Research: proving that emerging markets are no longer the most risky ones, especially Russia. Retrieved from informational and analytical portal "BKS Express": https://bcs-express.ru/novosti-i-analitika/issledovanie-dokazyvaem-chto-razvivaiushchiesia-rynki-bol-she-ne-samye-riskovye-osobenno-rossiia

\section{Information about the authors}

Alina Urazbaeva - third year student "International economics and business", Graduate School of Economics and Management, Ural Federal University (19, Mira str., Yekaterinburg, 620002, Russia); e-mail: alina.urazbaeva2000@gmail.com

Valentin Voytenkov - third year student "International economics and business", Graduate School of Economics and Management, Ural Federal University (19, Mira str., Yekaterinburg, 620002, Russia); e-mail: voivall@yandex.ru

Rogneda Groznykh - junior researcher of Laboratory of International and regional Economy, Graduate School of Economics and Management, Ural Federal University (19, Mira str., Yekaterinburg, 620002, Russia); e-mail: rogneda.groznykh@urfu.ru

ARTICLE INFO: received July 2, 2020; accepted August 28, 2020

\section{Информация об авторах}

Уразбаева Алина Руслановна - студент третьего курса ОП «Мировая экономика и международный бизнес» Уральского федерального университета (620002, Россия, г. Екатеринбург, ул. Мира, 19); e-mail: alina.urazbaeva2000@gmail.com

Войтенков Валентин Александрович - студент третьего курса ОП «Мировая экономика и международный бизнес» Уральского федерального университета (620002, Россия, г. Екатеринбург, ул. Мира, 19); e-mail: voivall@yandex.ru

Грозных Рогнеда Ивановна - младший научный сотрудник Лаборатории международной и региональной экономики Уральского федерального университета (620002, Россия, г. Екатеринбург, ул. Мира, 19); e-mail: rogneda.groznykh@urfu.ru

ИНФОРМАЦИЯ О СТАТЬЕ: дата поступления 2 июля 2020 г.; дата принятия к печати 28 августа 2020 г. 